\title{
Analysing Speech Acts in Buhari's Address at the 71st Session of the UN General Assembly
}

\author{
Innocent Sourou Koutchadé \\ Department of English, Abomey-Calavi University, 01PO box 526, Cotonou, Republic of Benin \\ E-mail: koutchade2@yahoo.fr
}

Received: 18-12-2016

Accepted: 25-01-2017

Advance Access Published: March 2017

Published: 01-05-2017

doi:10.7575/aiac.ijalel.v.6n.3p.226

URL: http://dx.doi.org/10.7575/aiac.ijalel.v.6n.3p.226

\begin{abstract}
This article aims at examining the language of a political speech through the linguistic theory of pragmatics. The focus of the study is, specifically, to identify speech acts used in Buhari's address at the $71^{\text {st }}$ session of the UN General Assembly. Such an analysis is meant to emphasize the way the Nigerian president conveyed his intentions and his country's priorities in line with the general theme of the Assembly. The paper has adopted Searle's (1969) speech act theory. The identification of illocutionary acts in the speech through a tabulated statistics shows that there are $52.56 \%$ of representative acts, $19.23 \%$ of directive acts, $16.66 \%$ of expressive acts, $11.53 \%$ of commissive acts and $00 \%$ of declaration acts. The findings reveal the dominance of representative illocutionary acts showing that Buhari has mainly expressed his beliefs regarding the theme of the assembly and the priorities of his country. Directive acts are used to make suggestions whereas commissives are used to point out the challenges to be taken up by Buhari and his audience and expressives reflect his psychological state while addressing the world leaders. The paper concludes that this study of speech acts has made it easy to comprehend the message of the Nigerian president in his address.
\end{abstract}

Keywords: Political speech, General Assembly, Pragmatics, speech acts, illocutionary acts

\section{Introduction}

Pragmatics and semantics are concerned with the investigation of meaning. The main difference between the two linguistic concepts is that semantics deals with meaning in words, phrases and sentences whereas the study of intended meaning in a given context falls within the domain of pragmatics. The focus of this study is a pragmatic analysis. According to Leech (2007), the pragmatic analysis of language is the investigation into that aspect of meaning which is derived not from the formal properties of words and constructions, but from the way in which utterances are used and how they relate to the context in which they are uttered. The main topics of this branch of linguistics include: implicature, presupposition, speech acts and deixis (Huang, 2007; Mey, 2006, Yule, 1996). Speech act is one important feature of pragmatics which relates actions to language used. In this paper, the pragmatic feature of speech act is used to analyse a political speech. In fact, a political speech is an aspect of political discourse, i.e. a discourse whose main aim is to deal with political matters. This paper focuses on Buhari's political speech. It aims at finding out the intentions of the Nigerian President and the strategies used to persuade the world leaders at the General Assembly of the United Nations. As a matter of fact, the General Assembly of the United Nations, created in 1945, is an important policymaking and representative organ whose functions are to provide states with recommendations regarding international problems on the one hand, and to find solutions to problems that affect people at the political, economical, legal and humanitarian level, on the other (United Nations, 2016). It has 193 member states and every year head of states attend the General Assembly for the annual debate. The theme of the assembly is purposely chosen to match the critical ongoing situation in the world. Actually, various previous studies have investigated speech acts in political discourse, notably political campaigns, acceptance or inaugural speeches (Akinwotu, S. A. ,2013; Ayeomoni, M. O. \& Akinkuolere, O. S. , 2012, Adetunji, 2009 ; Babatunde \& Odepitan, 2009). However, a study which has dealt with the speech delivered during the General Assembly of the United Nations, is hardly found. This study aims at providing such a contribution.

\section{Theoretical Framework.}

\subsection{The meaning of speech act}

Language, as a means of communication, is generally a medium used to carry out a certain number of actions. Speech acts are, generally speaking, actions speakers perform when they produce sentences in a given context including promising, betting, greetings, blessing, swearing, etc. As observed by Searle (1969, p.16) quoted by Mey (2006, p.93), "the unit of linguistic communication is not, as has generally been supposed, the symbol, word or sentence, ....but rather the production of the symbol or word or sentence in the performance of the speech act".

As a matter of fact, any action performed through an utterance produced is meant to express three different acts. The first element is the locutionary act, which is the basic act of utterance, or producing a meaningful linguistic expression. 
The second is illocutionary act which is performed through the communicative force of an utterance; it is also known as illocutionary force. The third category of act is the perlocutionary act, concerned with what follows an utterance: the effect of an illocutionary act (Yule, 1996; Saeed, 2007). Actually, the illocutionary force of an utterance is also interpreted as speech act. It is important to say that there are specific situations for the performance of the speech act to be effective; these are known as felicity conditions.

\subsection{Classifying speech acts}

There are many classifications of speech acts but the most common one adopted in this study is Austin's (1969) classification which is also developed by Searle (1969). This classification accounts for five categories of speech acts (Finegan, 2007; Saeed, 2007; Mey, 2006; Yule, 1996; Akogbéto \& Koutchadé, 2014).

This includes:

- Representatives or assertives, which commit the speaker to the truth of the expressed proposition (i.e. asserting, claiming, reporting, etc.)

- Directives are intended to get the addressee to do something, i.e., to carry out an action: command, request, challenges, etc.

- Commissives, which commit the speaker to some future course of action (i.e. promising, threatening, offering). They express what the speaker intends.

- Declarations; they change the world through their utterance. Declarations bring about the state of affairs they name: blessing, hiring, firing, baptisms, etc.

- Expressives, which state what the speaker feels. They express a psychological state (i.e. greeting, apologizing, welcoming, congratulating, etc.)

Moreover, a speech act can be direct or indirect. A direct speech act involves a direct relationship between a structure and a function whereas an indirect speech act focuses on an indirect relationship between a structure and a function. It is an utterance the linguistic form which does not reflect its communicative purpose.

\section{Data analysis}

As said earlier, this article focuses on the analysis of Buhari's speech, through the speech act theory. This speech has been delivered on September 20, 2016, during the 71st session of the United Nations General Assembly in New York and made available on the internet. The analysis is based on Searle's (1969) categorization of speech act. In order to get a thorough appreciation of the linguistic analysis, identification of different speech acts has been carried out. The descriptive research design is adopted and quantitative and qualitative analytical approaches have been employed in the study.

\subsection{Statistical analysis}

Through the speech act identification, we have counted and tabulated each category of speech act in the Nigerian president address. This is summarized in table 1 below:

Table1. Statistics of speech acts

\begin{tabular}{lll}
\hline Acts & Frequency & Percentage \\
\hline Representative & 41 & $52.56 \%$ \\
\hline Directive & 15 & $19.23 \%$ \\
\hline Commissive & 09 & $11.53 \%$ \\
\hline Expressive & 13 & $16.66 \%$ \\
\hline Declarations & 00 & $00 \%$ \\
\hline Total & 78 & $100 \%$ \\
\hline
\end{tabular}

From the above table, one can notice the way speech acts are distributed. Indeed, representative speech acts are the most predominant. They rank first in the speech: [41 (52.56\%)]. This gives the impression that the speaker Buhari is committed to the truth of the utterances he has produced in his speech. Directive speech acts rank second. They are 15 in number, representing $19.23 \%$ of the total. This implies that Buhari's intention is to get the addressee to do something. As for expressive speech acts, they come third 13(16. 66\%). Their presence shows the way the Nigerian president expresses his attitudes and psychological state regarding some passages of his speech. Commissive acts rank fourth. Only 09 of them, which account for $11.53 \%$, are used in the speech. As a matter of fact, they indicate that the president is committed to perform some future actions. Finally, one can notice that declarations are non-existent, showing that Buhari has not produced any utterance which brings about a change in the states of affairs (Meyer, 2009). These various speech acts are used to reflect the illocutionary force of the different utterances produced by the Nigerian president in his speech. The performative verbs also facilitate the categorizations of each speech act produced. In that 
respect, a further investigation leads to study each type of speech act in the speech. This is carried out in the next subsection.

\subsection{Analysing category of speech acts}

To have a clear view of the distribution of the speech acts in the speech, we have summarized them, together with the sentences in which they occur, in table 2 below.

Table 2. Speech acts distribution

\begin{tabular}{|c|c|c|c|c|c|}
\hline $\begin{array}{l}\text { Speech } \\
\text { acts } \\
\text { category }\end{array}$ & Representatives & Directives & Commissives & Expressives & Declarations \\
\hline $\begin{array}{l}\text { Number of } \\
\text { sentences }\end{array}$ & $\begin{array}{l}4,5,6,9,11,12,15,16,18, \\
19,20,21,26,27,28,29, \\
31,33,34,35,36,38,39, \\
41,42,43,44,51,52,53, \\
\begin{array}{l}58,59,60,61,62,63,67, \\
70,71,76,77\end{array}\end{array}$ & $\begin{array}{l}7,8,22, \\
24,40,47, \\
48,49,50, \\
68,69,72, \\
73,74,75\end{array}$ & $\begin{array}{l}2,13,14,23 \\
25, \quad 32,54, \\
55,66\end{array}$ & $\begin{array}{l}1,3,10,17, \\
30,37,45,46, \\
56,57,64,65, \\
78\end{array}$ & \\
\hline
\end{tabular}

From the above table, the sentences displaying each speech act are clearly presented. We now reconsider each of them in the context of the president's speech

\subsubsection{Representative/Assertive speech acts}

As said earlier, representatives are mostly predominant. They include assertions made in $(4,5)$ where the illocutionary forces are meant to remind Mr President of the assembly and the audience of Buhari's first address of the year 2015 which marked the year he was elected Head of State and was opportune to deliver his first address. He has also informed them about the two events that marked that year which are: the gains of the Millennium Development Goals and the adoption of the 2030 agenda on Sustainable Development. He, then states, in $(6,9)$, what he thinks to be true about the two events. Similarly, the representative speech act in (11) proves to be a statement of fact, as Nigeria has yet to reach its level of development. Consequently, Buhari's utterance in (12) is an assertion about the different axes to be touched as far as the reforms aiming to improve the economic level of the country are concerned. The utterance: "we are, however, undeterred and have embarked on a wide range of reforms. . ." is a proof that he has decided to take decisive actions that will help boost the country's economy. Similarly, utterances in $(15,16,17,18,19,20,21)$ display cases of representatives speech acts through which the Nigerian head of state in (15) recalls some of the challenges to be taken up in his administration (Koutchadé, 2015), i.e., fighting against corruption. This is why in (16), he uses the representative illocutionary act to briefly insist on the drawback of corruption. Indeed, he states the different steps taken to tackle the phenomenon in $(17,18,19)$, which as he believes, matches the various resolutions of the world anticorruption summit accounted for in $(20,21)$. Representative illocutionary acts are also used to address the issue of climate change. For instance, they are identified in $(29,30,31,34,35,36,38,39)$. The utterances in $(29,30,31)$ show the way this problem has been discussed in Paris at COP 21, whereas in the remaining sentences mentioned above, he describes, asserts, and concludes about the extent to which Nigeria has taken measures to face the consequence of climate issue and environmental deterioration. Moreover, representative illocutionary acts in (43, 44, 51, 52, 53, 58, 59, $60,61,62,63)$ are also used to refer to the topic of terrorism in the world in general and in Nigeria in particular. For example, the utterance verbs "to defeat, has been severely degraded, have been limited" in $(51,52)$ encode the act of reporting and concluding about how Boko Haram is being defeated. Finally, representative illocutionary acts are used in $(67,70,71,76,77)$. In these sentences, Buhari accounts for his belief about such issues as youth empowerment, nuclear security and international security.

\subsubsection{Directive speech acts}

As displayed in the above table, directive speech acts are identified in $(7,8,22,24,40,47,48,49,50,68,69,72,73$, $74,75)$. The peculiarity, in this speech, is that all the performative verbs expressing the directive illocutionary acts are modal verbs. This means that instead of getting his audience to things directly, Buhari has used indirect speech acts in a declarative form to make suggestions and requests. In $(7,8)$, he uses the modal "must" to call for the mobilization and the collaboration of everybody to take up the challenges the whole world is facing, including poverty, climate change, and youth empowerment. Similarly, the utterance used in (22) is the expression of Buhari's desire for the member states to sign the United Nations Convention against Corruption and he uses the modal "should" in (24) to strongly suggest the main theme to be discussed during the conference to be taking place in the US and UK in Washington next year, i.e., the speedy and unconditional return of stolen public assets. Actually, this is one of the main targets to be achieved by Buhari in his country, Nigeria where the public funds have been siphoned off for years by some leaders of the country. In his acceptance speech (Koutchadé, 2015), he has shown his strong will to eradicate corruption through a number of drastic measures. In order to reinforce his commitment for sustainable development through the cleaning of 
Ogoniland in Nigeria, Buhari has used directive illocutionary act, in (47), to request for further assistance of the developing nations to back up Nigeria efforts on the program.

Moreover, the modal verbs "should" in $(47,48)$ and "must" in (49) are used to display directive illocutionary force to suggest how he thinks terrorism should be tackled and fought. This relies on the strategic and collective and focused measures used to take up the challenge and the fight against the proliferation of small arms and light weapons which can become a reality through the signature and ratification of Arms Trade Treaty (ATT) as suggested by Buhari in (49, 50). Similarly, directive illocutionary acts occur in $(68,69)$ to request for the encouragement and empowerment of the youth not only in Nigeria, but also in the rest of the world. Finally utterances used in $(72,73,74,75)$ also display directive illocutionary acts. In (72), he uses the modal verb "must" to suggest that there is necessity for every nation, including Nigeria to join hands in order to put an end to the proliferation of nuclear arms. The directive illocutionary forces in $(73,74,75)$ are produced by Buhari to put forward the idea of United Nations Security Council reform that will take into account an equal representation of member countries and directed to tackling the major challenge of the present times.

\subsubsection{Expressive speech acts}

As said earlier, various directive illocutionary acts are used by president Buhari in his speech and have been identified in $(1,3,10,17,30,37,45,46,56,57,64,65,78)$. In (1), Buhari expresses his pleasure and joy about the election new president, Mr. Peter Thomson, of the 71st General Assembly and uses the illocutionary phrase "express my appreciation" to display a psychological attitude of satisfaction toward his predecessor, Mr. Mogens Lykketoft. Buhari, an informed president has shown his approval regarding the theme of the Assembly which is: "sustainable development goals; a universal push to transform the world". Likewise, Buhari has used the expressive illocutionary force in (17) through the illocutionary verb "I am pleased..." to praise the collective efforts used to recover the stolen assets. Buhari has also expressed his likes regarding some international meetings. For instance, he uses the illocutionary verb "is proud" in (30) to show what he feels about Nigeria participation in COP 21 in Paris in December 2015. Likewise, he uses the illocutionary verb "support" as a way of praising the effort made by the African Union to stop desertification. Moreover, the utterances used in $(45,46)$ are expressive acts in which the Nigerian president has shown a devout sympathy to the USA and the victims of the 9/11/2001 terrorist attack. The use of expressive illocutionary acts in (56, 57) shows how Buhari appreciates the assistance of Nigeria's neighboring countries such as Benin Republic, Cameroun, Chad, and Niger under the Multi-National Joint Task Force (MNJTF) to fight against Boko Haram on the one hand, as well as the efforts of international partners toward the eradication of terrorism, on the other. Finally, Buhari has expressed his country's support toward the Two-State solution with Palestinian rights to statehood in (64), whereas in (65) the use of the illocutionary verb "thank" is meant to appreciate UN and other aid agencies and development partners that have been sent to North East Nigeria. He ends the speech in (78) by expressing a psychological state through the statement of thanking the audience.

\subsubsection{Commissive speech acts}

Commissive speech acts occur in $(2,13,14,23,25,32,54,55,66)$. In this speech, they express Buhari's intention to perform a number of actions. First of all, he justifies the reason of the involvement of Nigeria in the next year General Assembly through himself as Head of the State by using the illocutionary verb "assure" in (2). This speech also serves as an avenue for the display of how he implements some of the government manifestoes including economic revival and reduction of standard of living of the State as expressed through the illocutionary phrase "our strategic objective is to stimulate the economy" and "we are taking measures to reduce the cost of governance" in $(13,14)$. In utterance (23), Buhari expresses the determination of his government to get back the public money that has been stolen whereas in (25) he uses the illocutionary verb "remains committed to" to display his intention to back up the a global coalition which promotes transparency and accountability in the management of revenues from the oil, gas and solid minerals sectors. Utterance (32) shows the determination of the president to implement some of the resolutions of COP21 in his country. On the other hand, human right preservation is one of the major preoccupations of Buhari. This is the reason why he uses commissive illocutionary acts to express Nigeria's efforts and commitment to protect human rights in various ways. Finally, the utterance (66) aims at showing how Buhari is commited to protect the interest of refugees in his country.

\section{Discussion}

The above analyses show how speech acts are used in the speech under study. As observed by Akmajian et al. (2010, p.396), illocutionary acts can often be successfully performed simply by uttering the right explicit performative sentence, with the right intentions and beliefs under the right circumstances. The analyses show that the various illocutionary acts identified are meant to display president Buhari intentions and priorities. The findings reveal that various speech acts are used. They include: representative illocutionary acts [41 (52.56\%)], directive illocutionary acts [15 (19.23\%)], expressive illocutionary acts [13 (16. 66\%)] and commissive illocutionary acts [09 (11.53\%)]. Following Huang (2007), Buhari has used representative acts to represent the world as he believes it is, thus making the words fit the world of belief. This means that Buhari has attempted to persuade his audience and express his own opinion regarding the ongoing challenges the whole world in general and his country, in particular, have to take up. Directive speech acts is meant to make the world match the words via the addressee. As for the expressive acts, they display the president experience. Finally, in commissive acts, the world is adapted to the words via Buhari himself. Actually, viewed from its context, Buhari's speech, turns out to be an opportunity to display the country's priorities according to the main topic of this year's meeting which is "the sustainable development goals: a universal push to 
transform our world". As a matter of fact, Buhari's beliefs, expressed through representative speech acts aims at showing the world how his country will contribute to the implementation of the UN's sustainable development goals. In fact, the Nigerian government, as shown by Buhari, has started to make great efforts towards the diversification of the country's economy and through the development of the country's infrastructures and the encouragement of foreign direct investment, with a special focus on the improvement of primary sector and industrialization. Nevertheless, this reform cannot be possible without the implementation of anti-corruption strategies which have started to yield possible results as the government has succeeded in recovering loots inside and outside the country. In addition, Nigeria is and continues to be committed to the transparent and accountable management of oil revenues. Buhari has also raised his audience's awareness on climate change which has caused the drying of Lake Chad and informs this audience that the cost of replenishing it has been put at 14 billion US Dollars under a five-year plan. Buhari also insists that it should be a global concern. Moreover, Buhari has announced that the fight against Boko Haram is in conformity with human right practices and also accounts for the success of the Nigerian army as the capacity of the terrorist group to carry out the organized attack has been reduced. Finally, the president has called for, through directive speech acts, the reform of the United Nations Security Council. This can facilitate the appropriate representation of continent like Africa.

\section{Conclusion}

On the whole, this study has inquired into the language of the Nigerian president's speech. Speech act analyses have shown how Buhari has disclosed the real motivations and aspirations of his country. This has aimed to show the world leaders that Nigeria as the first economic power and the most populated country of West Africa has got a say in the different issues addressed at the world summit which is the UN General Assembly. Therefore, it is clear that the expected circumstances for the performance of these speech acts performed, i.e., the felicity conditions are met. The Nigerian president cannot but display, truly, all these conditions especially in this year 2016 where the world economic crisis has become a real challenge to be taken up by all the Nigerians and Buhari has been severely castigated in the social media for not taking adequate measures to alleviate the sufferings of his citizens. Through the analysis of speech acts and the social context in which they occur, this article has shown the different actions carried out or to be carried out by president Buhari to solve various problems confronting his country and the whole world at the 71st Session of the UN General Assembly.

\section{References}

Adetunji, Akin. (2009). Speech acts and rhetoric in the second inaugural addresses of Nigeria's President Olusegun Obasanjo and America's President George W. Bush. In Odebunmi. A, Arua. E and Arimi. S. (Ed), Language, genre and politics. (A festschrift for Y.K. Yusuf). 275-296.

Akinwotu, S. A. (2013). A Speech Act Analysis of the Acceptance of Nomination Speeches of Chief Obafemi Awolowo and Chief M.K.O. Abiola. English Linguistics Research. 2(1),43-50.

Akmajian et al. (2010). Linguistics : an Introduction to Language and Communication.(6 ${ }^{\text {th }}$ edn). New Delhi: PHI Learning Private Limited.

Akogbeto, P. \& Koutchadé, I. (2014). "Pragmatic Analysis of Amma Darko's Beyond the Horizon". MultiFontaines. 1(1), 55-71.

Austin, J.L. (1962). How to Do Things with Words. London: Clarendon Press.

Ayeomoni, M. O. \& Akinkuolere, O. S. (2012). A Pragmatic Analysis of Victory and Inaugural Speeches of President Umaru Musa Yar"eAdua. Theory and Practice in Language Studies, 2 (3), 461-468

Babatunde. S and O. Odepitan. (2009). Pragma-Rhetorical Strategies in selected speeches of Olusegun Obasanjo. In Odebunmi. A, Arua.E and Arimi.S (Ed.), Language, gender and politics. (A festschrift for Y.K. Yusuf) 275-296.

Buhari's Speech at the 71st Session of the UN General Assembly. (2016 September 21). 360 News Local News. Retrieved from https:/www.360nobs. com/2016/09/536303.

Finegan, E. (2007). Language: its Structure and Use. (5 $5^{\text {th }}$ edn). Boston: Thomson Wadsworth

Huang, Y. (2007). Pragmatics. Oxford: Oxford University Press

Koutchadé, I. S. (2015). Discourse Analysis of General Muhammadu Buhari’s Official Acceptance Speech: A Systemic Functional Perspective. International Journal of English Linguistics, 5(5), 24-36. http://dx.doi.org/10.5539/ijel.v5n5p24.

Leech, G. N. (1983). Principles of Pragmatics. New York: Longman.

Leech, N. G. \& Short, H. M. (2007). Style in Fiction: A Linguistic Guide to English Fictional Prose (2nd ed.). London: Longman.

Levinson, S.C. (1980). Speech Act Theory: The State of the Art. Cambridge: University Press.

Leech, G. N. (1983). Principles of Pragmatics. New York: Longman.

McGregor, W. (2009). Linguistics: An Introduction. London: Continuum.

Mey, J. L. (2006). Pragmatics: An Introduction. (2 ${ }^{\text {nd }}$ ed). Australia: Blackwell Publishing.

Meyer, C. F. (2009). Introducing English Linguistics. Cambridge: Cambridge University Press. 
Saeed, J. I. (2007). Semantics. (2nd edn). Oxford: Blackwell Publishing.

Searle, J.R. (1969). Speech Acts. Cambridge: Cambridge University Pres

Searle, J. R. (1975), "Indirect speech acts", in P. Cole and J. L. Morgan (eds), Syntax and Semantics, vol. 3, New York: Academic Press, pp. 59-82.

United Nations (2016). Functions and Powers of the General Assembly. Retrieved from www.un.org/en/ga/about/backgroung.shtml.

Yule, G. (2007). The Study of Language.(7th edn) Cambridge: Cambridge University Press

Yule, G. (1996). Pragmatics. Cambridge: Cambridge University Press.

Appendix: Speech acts identification.

The identification of speech acts is carried out according to the following keys:

\section{Rep $=$ representative, Dir $=$ directive, Exp $=$ expressive, Com $=$ Commissive, Dec $=$ declaration .}

1-Mr. President let me, on behalf of the Government and People of Nigeria, congratulate you on your well-deserved election as the President of the 71st General Assembly (Exp). 2- I assure you of Nigeria's support in steering the affairs of the General Assembly in the next one year (Com). 3. I take the opportunity to also express my appreciation to your predecessor Mr. Mogens Lykketoft, for the achievements recorded during his tenure (Exp). 4. Mr. President, Last year, I presented my first address to the General Assembly after my assumption of office as President of the Federal Republic of Nigeria (Rep). 5. Indeed, it was a remarkable year, which not only celebrated the gains of the Millennium Development Goals, but also witnessed the adoption of the 2030 agenda on Sustainable Development (Rep). 6. These landmark achievements by the global community, will no doubt build a more prosperous, all inclusive world (Rep).

7. We must work together to liberate humanity from poverty, save our planet from the devastation of Climate Change and rid the world of terrorism for a more peaceful and prosperous future (Dir). 8. We must remain committed to taking bold steps to transform our world (Dir) 9. The Sustainable Development Goals underscore the imperative for our collective will towards finding enduring and sustainable solutions to addressing global disparities (Rep). 10. It is in the light of our appreciation of the enormity of the task before us, that I welcome the theme of this Assembly, 'Sustainable Development Goals; a Universal Push to Transform the World.(Exp)' 11.Mr. President, Nigeria as a developing country has been adversely affected by the global economic downturn (Rep). 12.We are, however, undeterred and have embarked on a wide range of reforms in our efforts to diversify our economy and shift emphasis to mining, agriculture, industrialization, infrastructure development and the creation of the enabling environment for Foreign Direct Investment (Rep).

13. Our strategic objective is to stimulate the economy, restore growth and accelerate recovery (Com). 14. In doing this, we are taking measures to reduce the cost of governance and increase expenditure on infrastructure and ensure environmental best practices (Com).

15. Mr. President, fighting corruption remains a cardinal pillar of our administration (Rep). 16. Corruption freezes development, thereby undermining the achievement of the Sustainable Development Goals (Rep). 17. I am pleased that our efforts in fighting corruption are yielding positive results including significant stolen assets recoveries (Exp).

18. The recovered funds are being channelled towards the development of critical infrastructure and the implementation of social inclusion programmes for our people (Rep). 19. We are also strengthening our capacity of government entities to institutionalize reforms to ensure transparency and good governance (Rep).

20.The Anti - Corruption Summit held in London in May this year served as further reassurance of the global community's commitment to fight corruption through the proposed practical steps to address the challenges including actions to hold perpetrators to justice within the law (Rep). 21. Nigeria supports the development of an international legal framework to enforce anti-corruption measures and strengthen existing international institutions to effectively deal with corrupt practices (Rep).

22. Nigeria calls on Member States that are yet to sign up to the United Nations Convention against Corruption (UNCAC) to do so (Dir). 23. Nigeria will continue to advocate for the facilitation of the recovery of illicit financial assets (Com). 24. Indeed, the speedy and unconditional return of stolen public assets should be the focus of the followup anti-corruption conference to be hosted by the US and UK in Washington next year (Dir).

25. Furthermore, Nigeria remains committed to the Extractive Industries Transparency Initiative (EITI), a global coalition which promotes transparency and accountability in the management of revenues from the oil, gas and solid minerals sectors (Com). 26. We voluntarily signed up to EITI because we are convinced that transparent governance is an imperative for resource-rich developing countries like ours (Rep).

27. Through the work that our national chapter of EITI has done over the years, it is clear that our faith is not misplaced (Rep). 28. The National EITI has been empowering citizens with critical information they can use to hold government and other players in the extractive industries to account, and make recommendations that drive reforms in these strategic sectors of our national life (Rep). 
29. Mr. President, The world took a giant step in Paris, towards addressing the challenges of Climate Change (Rep). 30. Nigeria is proud to have been part of the process leading to the adoption of the Paris Agreement in December 2015 at the 21st meeting of the Conference of Parties to the United Nations Framework Convention on Climate Change (Exp).

31.COP- 21 marked a watershed in the global community's commitment to address climate change and we will continue in our determined efforts to reduce Green House Gas (GHG) emissions (Rep).

32. At the centre of Nigeria's climate action is our determination to implement the strategies in our Intended Nationally Determined Contributions (INDCs), which will foster low carbon economy and sustainable growth in building a climate resilient society (Com). 33. We are creating public awareness through the integrated involvement of the private sector and civil society, and strengthening national institutions and mechanisms (Rep).

34. The negative consequences of Climate Change have manifested in the drying up of our Lake Chad (Rep). 35.The means of livelihood of an estimated 30 million inhabitants of the Lake Chad Basin, spread across Cameroun, Chad, Niger and Nigeria, are being severely threatened (Rep). 36. The cost of replenishing the lake has been put at 14 billion US Dollars under a five year plan which should be accorded global attention (Rep). 37. Nigeria also supports the African Union initiative on the Great Green Wall to halt desertification (Exp).

38. In furtherance of our commitment to environmental sustainability, Nigeria has launched the cleanup of Ogoni land in Nigeria's Niger Delta, based on the 2011 Environmental Assessment of the area by the United Nations Environment Programme (Rep). 39. Multi-national oil companies operating in the area will be required to live up to their corporate social responsibilities and contribute to the cleaning-up of the environment degraded as a result of their activities and operations (Rep). 40. We call on development partners and multinationals to support our efforts, through the Ogoniland Restoration Fund (Dir).

41. Mr. President, the 21 st century has been marked by the rising insecurity unleashed by global terrorism and violent extremism indeed, which constitute a real threat to the international community (Rep). 42. With the global increase in the spate of terrorist attacks, there is now, more than ever before, international consensus and greater willingness to collaborate in combating this threat (Rep).

43. Indeed, we are meeting at the time when our hosts, the American people have just marked the 15 th Anniversary of the tragic and dastardly terrorist attacks on their soil (Rep). 44. We in Nigeria, having been victims of terrorism of ourselves fully understand the impact of $9 / 11$ on the American psyche and the families of the thousands of innocent victims whose lives were lost that day (Rep). 45. I therefore, reiterate the Nigerian Government's and people's sympathies to the American people and prayers for the families of the victims that they may heal and find closure soon (Exp).

46. We hope that justice will be done to the families of victims of $9 / 11$ as indeed to those victims of terror everywhere in conformity with the norms of international justice (Exp). 47. As we seek justice for terror victims, the international community should avoid reacting in the heat of deep emotions of the moment by taking unilateral measures, legal or otherwise that will have a negative and disruptive impact on the international community's collective efforts to fight terrorism (Dir).

48. We should not be distracted in our collective resolve to beat back terrorism in all its forms (Dir). 49. As we confront terror we must also commit to stopping the proliferation of small arms and light weapons which nurture its spread (Dir). 50. To this end, Nigeria urges member States that are yet to sign and ratify the Arms Trade Treaty (ATT) to do so without further delay (Dir).

51. Nigeria has made remarkable progress in our resolve to defeat Boko Haram whose capacity to launch orchestrated attacks as a formed group has been severely degraded (Rep). 52. In the last few months, their operations have been limited to sporadic use of Improvised Explosive Devices (IEDs) against soft targets (Rep).

53. Nigeria has continued to combat terrorism based on the established rules of engagement and in conformity with international best practices (Rep). 54. I take this opportunity to reaffirm Nigeria's commitment to human rights norms and International Humanitarian Law in our efforts to counter terrorism and violent extremism (Com). 55. I also wish to restate the assurance that the Federal Government of Nigeria is employing all our judicial tools to investigate and treat reported cases of human rights violations(Com).

56. I commend the contribution of our neighbours - Benin Republic, Cameroun, Chad, and Niger whose combined efforts under the Multi-National Joint Task Force (MNJTF) accomplished the present return of normalcy in areas hitherto occupied by Boko Haram (Exp).

57. May I also thank our international partners, including France, the United States, the United Kingdom, Germany, the United Nations, ECOWAS the African Union and many other multilateral and bilateral partners for their invaluable support (Exp). 58. Our experience today is evidence that with determined international collaboration, terrorism can be defeated (Rep).

59.Mr. President, the flow of refugees and migrants worldwide has attained alarming proportions (Rep). 60. In this wise Nigeria supports the Ceasefire Agreement brokered by the United States and Russia to end the atrocious tragedy of the Syrian civil war (Rep). 61. Of particular concern to us in Nigeria is the plight of Internally Displaced Persons (IDPs) arising from Boko Haram terrorism (Rep). 62. We have taken concrete steps to address their humanitarian needs and to ensure that necessary conditions are established to enable the voluntary return of the displaced persons to their places of abode in safety and dignity (Rep). 
63.Mr. President, at the same time, the Palestinian issue, despite years and years of international efforts is no nearer to being resolved (Rep). 64. Nigeria in company with member States of the African Union, firmly support the Two-State solution with Palestinian rights to statehood in conformity, with numerous Security Council Resolutions beginning with Resolution 242 of 1967(Exp).

65. Let me seize this opportunity to once again thank all UN and other aid agencies and development partners currently deployed in North East Nigeria (Exp). 66. I reaffirm Nigeria's commitment to collective action towards an effective global response to address the root causes of refugee flows worldwide (Com).

67. Mr. President, we acknowledge the importance of youth in national development and remain committed to harnessing the potential of the increasing youth bulge (Rep). 68. We must take advantage of the numbers and creative energy of young people who are in the majority in Nigeria and in most other member states (Dir). 69. Therefore, at the international level, we call for the establishment of a specialized UN agency for youth development to achieve this strategic objective (Dir).

70. Nuclear security remains central to our quest for durable peace and security (Rep). 71. This was why I participated in the 5th Nuclear Security Summit hosted by President Barak Obama in Washington in March, 2016 (Rep). 72. Nigeria and the other peace-loving member States of the United Nations must continue to uphold the fundamental principles of nuclear disarmament non-proliferation and its peaceful uses (Dir).

73. Mr. President, the United Nations should now redouble the long protected effort for its reform to enable it to effectively address the challenges of our times (Dir). 74. Nigeria, therefore, reiterates its call for the reform of the United Nations Security Council, in particular to reflect equitable and fair representation and greater transparency, legitimacy and inclusiveness in its decision making (Dir).

75. Africa should be adequately represented on the United Nations Security Council in the permanent member category (Dir). 76. In this regard, Nigeria stands ready to serve Africa and the world on a reformed security council to advance international peace and security (Rep).

77. Mr. President, let me conclude by reaffirming Nigeria's abiding faith in the United Nations and in her capacity to support Member States to deliver on the 2030 Agenda for Sustainable Development (Rep).

78. I thank you (Exp). 